Human Error

\section{1. ヒューマンエラーとは}

\section{1 逸脱した行為}

ヒューマンエラー(Human error)とは，D. Meister[1] によれば「期待される行為からの逸脱」であるという。 た とえば，テーブルの上にあるコップからコーヒーを飲もう (期待される行為)として手を伸ばしたところ, 手を差し出 す方向と位置が悪かったためにコップをテーブルから落と してしまった(逸脱)，という事例は，ヒューマンエラーの わかりやすい例である。ただし，この例でも皇うである が，落ち着いてコップの方向を見て手を伸ばしたのであれ ば，ヒューマンエラーは起こらない。この場合，他の人と 話をしていて手を伸ばしたとか，二重課題(dual task)を している場合とか，他に気を取られていてコップを視認し ていなかったといった注意の逸脱があったなどの別の条件 が付随している際に，ヒューマンエラーが起こるものであ る。この意味からいって, Meister の定義は非常にわかり やすい定義であるが, ヒューマンエラー発生の背因を述べ ず，結果だけについて述べた定義である，といえる。

\section{2 行動形成要因}

A. D. Swain[2]らはヒューマンエラーは 1 つの行動夕 イプであるとして，ヒューマンエラーに導く要因が背景に あると考え，それを行動形成要因(Performance shaping factor-PSF) と名づけた。彼はPSFには，(1)設備・環境に 起因するファクター, (2)マネジメントに起因するファクタ 一, (3)人的要因㲹起因するファクター，があるという.

たとえば，製紙工場の紙巻き取り用ローラーで手をはさ みもぎとられた災害事故を例として考えよう。ローラーが 高速で回転しているので，ローラーに近づくとは数跳ばさ れて死亡するかもしれないので，ローラー自体は危険な物 体(危険要因)である。災害事故が発生するのは高速回転時 ではなくて，巻き取り終了時にローラーが減速して間もな

原稿受付 1995 年 4 月 12 日

キーワード : Robot Safety, Human Error, Safety Guard Robot Working Area, Human-Robot Interraction

* 7739 東広島市鏡山 1-4-1

* Kagamiyama, Higashi hiroshima-shi, Hiroshima
く停止すると思われる時機であり，作業員が手を出して人 力で早く停めようとする時である. (1)の設備・環境の危険 ファクターは(3)の人的要因に起因するファクターと結合し て，ヒューマンエラーの形成要因と化する。また設備管理 や従業員安全管理が不十分なマネジメントは，ヒューマン エラーの形成要因となる。結局, (1)(2)(3)が相互に関連し て，ヒューマンエラーという行動の形成要因となる。

\subsection{3 つの認知レベル}

J. Rasmussen[3]は，ヒューマンエラーは起こったあ とでエラーとわかるという特性をもつので定義し難いとし ながらも，「システムの目的が果されない原因のひとつ」と 説明している，彼は有名な“意思決定の梯子”理論を展開 して, ヒューマンエラーの“3つの認知レベル”仮説をたて ている。皇れは(1)スキル・ベースの行動, (2)ルール・ベース の行動, (3)知識ベースの行動, のいずれか，あるいはすべて の組合せで生じるヒューマンエラーで解釈できるという．

スキル・ベースの行動では，適切なスキルをもっていな いためとか，慣れた定型的スキーマが優位となってエラー となる，といった類のものである。

ルール・ベースの行動では, 一連の行動はルール・ベー スから引き出されて発動するものであるが，行動の途中で 別のルールにスイッチングされてエラーとなるケース，が 当てはまる，たとえば，滑走路に近づいたが低すぎて「パ ワー全開」と機長が命じたが，副操縦士はパワー全開とと もに着陸ギアも引っ込めて胴体着陸となってしまった。 離 陸時のパワー全開のあとで着陸ギアの引き戻しをするとい ラルールに入ってしまったのである。

外界状況をサインとして認識したオペレータは, 知識ベ 一スとの照合と推論に基づいてメンタルイメージをもち, 意思決定を行うが，サインからあらゆる可能性の分析をす べきなのに，慣れ親しんだデータだけを取り込みもっと別 の方法があるのに，自己の方略に入り込んでしまう。

Rasmussen の認知レベル仮説は世界でもっとも信頼さ れている理論であり, Rouse, Reasonと引き継がれ, Reason $は$ GEMS (A generic error-modelling system)へ と展開している 4 ］. 


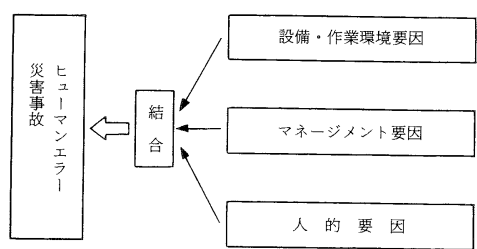

図 1 ヒューマンエラーや災害事故 が発生する関係図式

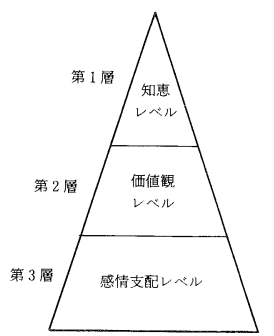

図 2 人間の三層理論

\section{4 三層理論}

長町は多くのヒューマンエラーの事例研究から図 1 の上 うな関連図を作った。ヒューマンエラー発生には，機器・ 環境側の人間工学的問題，マネジメントの欠陷，人的要因 の 3 つの要因が絡んでいる. とくに人的要因が基盤的要因 であり，それは図 2 のように，認知・価值志向・感情の三 層をもっており [5], 認知の不適切さがスキル適用と判断 の間違いを起こし, 価值志向のまずさが企業内の安全ルー ルの適用をやめさせ, 感情が自己本意な行動を触発する. この三層理論は NKY・IKY 理論と名づけられて, 日本と 米国で知られている.

\section{5 理論に基づく分析と対策}

これまで述べた欧米のヒューマンエラーの理論が認知心 理学の立場で構築されたものであるが，三層理論はとくに 感情 (Affect)を重視しており，1994 年の国際人間工学会 の特別講演で Reason がマネジメントと感情をとり入れる ように修正すると発言し，やっと感情がヒューマンエラー のひとつの要因として考えられるようになった。

\section{2. 産業用ロボットが関連する死亡事故}

\section{1 産業用ロボットによる死亡事故事例}

世界中で約 50 万台のロボットが稼動中であり，そのう ちの約半数が日本で動いているといわれている.1993 年 時点で長町が把握しているロボットが絡んだ死亡事故は, 米国で 2 件，日本で 17 件であり，圧倒的に日本での死亡 事故件数が高く，これは産業界へのロボットの普及比率か らいっても，日本はロボット災害国といえる。

日本で発生したロボットに絡んだ死亡事故の一覧表が, 表 1 である $[6]$. このうち，No. 4 及びNo.7の事例につ いて解説する。

\section{(1) No. 4 事例}

図 3 のように，建築材用の壁板(ベニヤ)の加工のため に，積み重ねた壁板を 2 枚ずつ自動的にローラーコンベア に載せる作業を行っていた。バキュームハットつきのオー トキャリアがプログラムに準じて移動していたが，不具合 があって停此したので，オペレータが近づき，壁板の積み 重ね(パイル)がずれているのに気づいてそれを手直しして いた時，不具合がな⿰七ってオートキャリアが壁板をつかみ

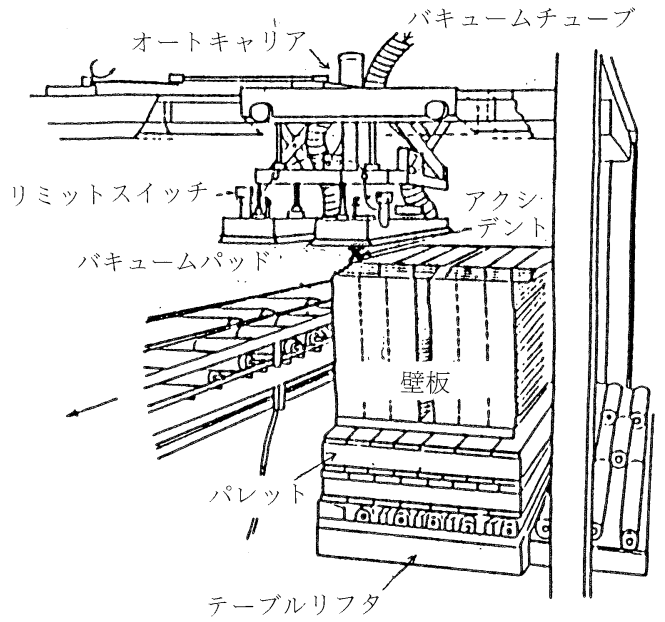

図 3 No. 4 の事例

に来たのに気づかず，バキュームパッドと積み重ねられた 壁板との間に頭部を押しつけられて死亡した。

( 2 ) No. 7 事例

FRP 材でできた石油採掘用パイプの磨耗を示すディプ スゲージ削り出し作業場での死亡事故である。ロボットで あるオートローダに対する安全対策として，ロボットの作 動区域を柵で囲んでいたが，事故発生当日は加工機の不具 合の修理を行っていた。

パイプの磨耗を示す溝を削り出すためのミルスロットの 不具合がなおったので，一度試し削りをすることになり， 加工機を動かした後，オペレータが通常の状態で柵の外か らディプスゲージで溝の深みを測定していた。その時に, 柵の中にいた別の作業者が，深みを目視で測定しようと身 をのり出した際，オートローダーが下降する時であって， その作業者の頭をつかみ死亡させてしまった。

\section{2 産業ロボットに関係したヒューマンエラー}

表 1 を簡単に整理してみよう。安全衛生法施行令により 産業用ロボットを使用する場合, 作業者がロボット稼動中 に可動区域に入れないように柵を構じインターロックを取 りつけることになっている。ところが，安全柵が設置され ていても死亡事故が発生しているのが，問題点なのであ る.

作業者がロボット可動区域に入る目的として，(1)教示 (ティーチング)の作業及びその結果の確認のため, (2)作業 開始の点検，定期検查のため，(3)調整，修理及びこれらの 結果の確認のため, (4)運転中のトラブル発生のための応急 措置のため，(5)作業者の判断ミス，と分類すると，表 1 の ようにそれぞれの災害事故を分類することができる。

ここで, 教示中の災害事故は 17 件中 1 件のみ, (5)判 断ミスは 17 件中 3 件であり，(3)及び(4)は修理もしくはト ラブルシューティングが目的なので一緒にすると，17 件 中 13 件 $(77 \%)$ と非常に多い。法的に安全対策をしていれ 
表 1 産業ロボットが関係した死亡災害発生状況

\begin{tabular}{|c|c|c|c|c|}
\hline No. & 発生日 & 種 & 発 生 状 況 & $\begin{array}{l}\text { 侵入 } \\
\text { 目的 }\end{array}$ \\
\hline 1 & 1978.10 .25 & 建設用機械製造業 & $\begin{array}{l}\text { コンベア上の加工不良の加工物を両手で持ち上げて除去しようと動かしたとき, ロボット } \\
\text { (auto-loader)の作動用のリミットスイッチが作動し, ロボットに背中を押えつけられた。 }\end{array}$ & (4) \\
\hline 2 & 1981.7 .4 & $\begin{array}{l}\text { 輸送用機械器具製 } \\
\text { 造業 }\end{array}$ & $\begin{array}{l}\text { 機械の調整後, 起動ボタンを押したところ, 背後の産業用ロボット(加工材の送給・取り出 } \\
\text { し用)のマニピュレータがのびて, マニピュレータと機械の間に身体をはさまれた。 }\end{array}$ & (3) \\
\hline 3 & 1983.6 .22 & 包装業 & $\begin{array}{l}\text { 新聞用のロール紙の包装の際, 小口面への包装紙貼り付けを行う産業用ロボットのアーム } \\
\text { とフレームの間に頭をはさまれた。 }\end{array}$ & (5) \\
\hline 4 & 1984.2 .24 & 建築材製品製造業 & $\begin{array}{l}\text { アームの先にバキュームパッドをもつ産業用ロボット (auto-carrier)が壁板をローラーコ } \\
\text { ンベアに乗せる作業を行っていたが, トラブルが発生し, 被災者が調整を行っているとこ } \\
\text { ろをバキュームパッドと壁板の間にはさまれた. }\end{array}$ & (4) \\
\hline 5 & 1984.4 .26 & $\begin{array}{l}\text { その他の設備工事 } \\
\text { 業 }\end{array}$ & $\begin{array}{l}\text { 無人搬送を行う産業用ロボットの据え付け調整中, ロボットにエラーが生じ, 自動的に原 } \\
\text { 点復帰作動をして作業員をひいてしまった. }\end{array}$ & (1) \\
\hline 6 & 1984.9 .5 & $\begin{array}{l}\text { コンクリート製品 } \\
\text { 製造業 }\end{array}$ & $\begin{array}{l}\text { コンクリートブロックを数十個まとめて搬送する産業用ロボットの運転中, ブロックが正 } \\
\text { しく並んでいなかったので被災者が修正していたところ, アームが降下してきてブロック } \\
\text { との間にはさまれた. }\end{array}$ & (3) \\
\hline 7 & 1984.11 .19 & $\begin{array}{l}\text { 一般機械器具製造 } \\
\text { 業 }\end{array}$ & $\begin{array}{l}\text { ツールジョイント加工ラインのミルスロット(溝)加工箇所で同僚がディプスゲージで溝の } \\
\text { 梁さを測定中に被災者が, その様子を見ようとして身をのり出したところ, ローダーハン } \\
\text { ドが降下して, 頭部をはさまれた. }\end{array}$ & (3) \\
\hline 8 & 1985.7 .2 & $\begin{array}{l}\text { 自動車・同付属品 } \\
\text { 製造業 }\end{array}$ & $\begin{array}{l}\text { クォーターアウターR 搬送装置の異常原因を点検するため } 2 \text { 階の安全構内に入っていた } \\
\text { 被災者が, 下降してきたドロップリフターとレールの間に頭部をはさま机た. }\end{array}$ & (3) \\
\hline 9 & 1986.10 .1 & その他の化学工業 & $\begin{array}{l}\text { 自動倉庫のスタッカー式クレーンを手動に切り換えてケーブルの接続チェックを } 2 \text { 名で行 } \\
\text { っているときに端子ボックスのふたが落ちたので, これを拾うため } 1 \text { 名が柱と端子ボック } \\
\text { スの間に頭をはさまれた. }\end{array}$ & (5) \\
\hline 10 & 1987.1 .20 & $\begin{array}{l}\text { 自動車・同付属品 } \\
\text { 製造業 }\end{array}$ & $\begin{array}{l}\text { 自動プレスラインに設けられた自動送給装置のフィードバーに取り付けられたセンサを修 } \\
\text { 理中, そのセンサの動きを確認しようとして稼動中のフィードバーとプレス下金型に設け } \\
\text { られているガイドポストの間に頭部をはさまれた. }\end{array}$ & (3) \\
\hline 11 & 1987.10 .31 & 卸売業 & $\begin{array}{l}\text { 自動倉庫のクレーンの走行路において, 走行してきたクレーン(棚に荷をのせたパレット } \\
\text { を出し入れするクレーン)の荷台と棚の間に胸部をはさまれた。 }\end{array}$ & (3) \\
\hline 12 & 1989.7 .7 & 食品製造業 & $\begin{array}{l}\text { 荷取り扱いロボットに付設されているコンベアの荷の流れ調整に際して, ロボットの運転 } \\
\text { を停止せずにロボットの可動範囲に入り, マニピュレータと荷フィーダの間にはさまれた. }\end{array}$ & (3) \\
\hline 13 & 1989.12 .13 & 自動車製造業 & $\begin{array}{l}\text { ロボットライン工程のタイヤ取り付け工程においてナット締め付け用ロボットが異常を起 } \\
\text { こし, 作動が止まったため可動範囲内に入って修理していたところ, ロボットが突然動き } \\
\text { だしマニピュレータに胸を打たれた. }\end{array}$ & (3) \\
\hline 14 & 1989.9 .19 & 自動車製造業 & $\begin{array}{l}\text { 鋳造ラインに拈いて, ワークを搬送するローダーのクランプに何らかの目的で可動区域に } \\
\text { 入った被災者がはさまれた. }\end{array}$ & 不明 \\
\hline 15 & 1990.6 .13 & 木材木製品製造業 & $\begin{array}{l}\text { ベルトコンベア上に設けられた不良品取り出し用の産業用ロボットのスイッチを切らずに } \\
\text { その調整を行っていた作業者が可動範囲に立ち入り, 起動用リミットスイッチに触れたた } \\
\text { めマニピュレータが作動し, マニピュレータとベルトコンベアの間にはさまれた. }\end{array}$ & (3) \\
\hline 16 & 1990.7 .9 & 印刷業 & $\begin{array}{l}\text { 新聞の印刷工場に拈いて, 印刷用紙(ロール紙)を自動的に接続するための仕立てを行う } \\
\text { “巻取紙仕立装置”のアーム可動範囲に同装置を停止せずに立ち入った被災者が, アームと } \\
\text { 同装置本体との間に胸部をはささまれた. }\end{array}$ & (3) \\
\hline 17 & 1990.9 .20 & 金属製品製造業 & $\begin{array}{l}\text { 全自動式パイプベンダーの操作者が肉薄鋼管の両曲げ作業に従事中, 回転する自動排出装 } \\
\text { 置のアームの可動範囲に立ち入りパイプ送りローラーカバーとの間にはさまれた. }\end{array}$ & (5) \\
\hline
\end{tabular}

ば，産業用ロボットが稼動中に作業者がその領域にとび込 むことは不可能である。ただし，ロボットに不具合が生じ た場合，修理後動かして確認する必要があり，その際に災 害事故が発生する可能性が生まれる。
もつと危険であるのは，ロボット用の安全対策が施され ていない企業の場合には，工程の中で不具合が発生した時 に，作業者がロボットの可動区域内に不用意に入ってしま う，という点である。しかも，より大きな人間工学的な問 


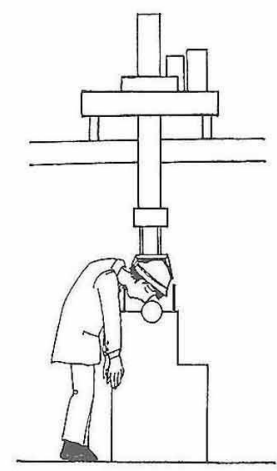

図 4 オートローダーのハンドで死亡した事例(No. 7)

題点は，プロセスの不具合のためにプログラムからの命令 を待っているロボットを，作業者は“停止”していると錯 䛊する点である．この停止は“待ちの停止”と“完了停止” との区別がつかない. 経験をもっているオペレータです ら，そうなのである。ここに，安全ルールを無視する人間 側の感情の働きを考えることが重要になってくる.

\section{3.ヒューマンエラーにおける感情の役割}

\section{1 再び三層理論}

図 2 の人間の三層理論は, 「認知 (知恵)」「価值志向」「感 情」で構成されていた，認知層が強くて大きければ感情層 が小さくなる，つまり逆三角形の構成となり，この場合に Rasmussenのモデルが当てはまる，ところが，感情層が 強くて大きいことは，情緒的自己中心的な行動をとりやす く，横着で省略行為が多くなる，この場合には，価值志向 も非安全側に向き, 認知層もアンバランスな特性をもつ.

ここで解説したNo. 4, 7 の死亡事故のうち No. 4 は, 作業者が不具合を発見して不用意にロボットの可動区域に 侵入している。“早く手なおしをしなければ”という気持 とロボットは“止まっている”という情緒的な作用が働い ている，こうした感情のために，一時的に危険領域である ことを忘れた事例が 17 件中 13 件も発生したわけである. 外国の災害事例も含めて，労働災害事故を人間工学的に分 析すると，感情支配による災害事故が 70〜 $80 \%$ も占める ほどである，最近発生した名古屋空港における中華航空機 の墜落事故を含めて, パイロットミスによる事例の中に は，感情支配加ら次つぎと複合なファクターを誘発してい る例が多い.

産業ロボットの予見行動について世界で初めて行った長 町の実験によると [6]，ほんの 3 秒もロボットが停止する と，ロボットに近づいても大丈夫という人が非常に多い. 二次元の世界で動く工作機械と比べて，ロボットの場合は 時間の次元を加えて四次元の世界で動いているものだか ら，人間には理解できないのかもしれない.

\section{2 産業ロボットのヒューマンエラ一対策}

ロボットは産業場面だけではなくて，ホームロボットの
開発や極限ロボットの導入などを考慮すると, 今後人間は ロボットと共存する空間が増えてくる。その時代になる と，人間とロボットとのハード的コンフリクトはますます 増大し，災害事故も増加することになるだろう。ロボット との安全な共存を実現するには，従来のようなヒューマン エラー対策に依存していては不可能である。つまり，人間 に三層理論が当てはまる限り，Rasmussen 型では限界があ ることになる.しかも, 感情支配の対策を立てることは可 能ではあるけれども $(\mathrm{NKY} \mathrm{IKY})$ ，不特定多数の人間がロ ボットと共存する限り，感情支配刘策にも限界がある.

では，ロボットに関するヒューマンエラー対策とは，安 価な知的認識システムをロボット及びロボットの可動領域 に組み込むことでヒューマンエラーが発生してもエラーと ならないシステムを構築することである。

長町らは，産業用ロボットの可動領域に安価なセンサを 床に埋め込むことで，ロボット側が人間の動き。方向・速 度を予測するシステムを作成し，シミュレーションにより 両者がコンフリクトを起こさないことを確認した［7］．安 価で簡単で信頼性が高い認識システムを開発することで, ヒューマンエラーが起こらないフェイル・セイフの世界を 創造しなければならない.

\section{参 考 文 献}

[1] D. Meister: "Human Factors, Theory and Practice," John Wiley \& Sons, 1971.

[2] A. D. Swain and H. E. Guttman: "Handbook of Human Reliabi1ity Analysis with Emphasis on Nuclear Power Plant Applica tions," U. S. NRC-NUREG/CR-1278, 1980.

[3] J. Rasmussen: "Information Processing and Human-Machine Interaction," Elsevier, 1986 （海保博之ほか共訳：インターフェース の認知工学, 啓学出版, 1990 年).

[4 ] J. Reason: "Human Error," University of Cambridge Press, 1990 (林喜男監訳: “ヒューマンエラー”, 海文堂, 1994 年).

[5] 長町三生: “安全管理の科学的知識,” 日刊工業新聞社, 1984 年.

[6] 長町三生, 穴山恭廣 : “産業用口ボットの人間工学的研究 (1)”, 人間 工学, 19(5), 259-264, 1983.

[7] M. Nagamachi: "An Attempt of Intelligent Implementation for Robot Safety," Presented at International Conference of Human Factors on Material Handling and Occupational Safety, 1994.

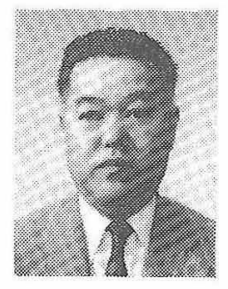

長町三生 (Mitsuo Nagamachi)

1936 年 2 月 12 日生. 1963 年広島大学大学院 博士課程修了. 文学博士. 広島大学工学部助 手, 助教授を経て 1978 年に教授. 感性工 学, 人間工学, 安全工学, ヒューマンインタ ーフェースなどの研究に従事. 日本人間工学 会理事，電子情報通信学会，計測自動制御学 会, 日本経営工学会, HFES(米国)などの会員.

(日本ロボット学会正会員) 